\title{
Penerapan Model 9P Dimensi Bauran Pemasaran Jasa Perbankan (Studi pada BPR di Propinsi Riau)
}

\author{
ARMAN \\ Sekolah Tinggi Ilmu Ekonomi Bangkinang \\ Jln. DR. A. Rahman Saleh No. 54 A Bangkinang. Telp. (0762) 20380. \\ E-mail : armanpiliang@yahoo.com
}

\begin{abstract}
Banking services become one of the unique options for its customers. This uniqueness is based on customers who are specialized in small and medium-sized micro businesses. There are many attempts to be done such as mortgage credit services until the effort to pick up the ball to its customers. Using 9P model of marketing mix of banking services and using survey method with sample in this research is BPR customer in Riau Province as many as 393 people and data collecting technique by using questioner then data analyzed by using descriptive technique. The result of the research is that the marketing service mix of BPR in Riau Province is in good category. This is due to the lack of availability of credit variations into service products at Bank BPR. Then also due to lack of suitability of variation of credit offered to the needs of BPR customers. Also, due to the low level of customer's ability to pay the installment payment of the RB, lack of availability of BPR service to customers. Lack of affordability of BPR customers coming to the service site and lack of information disclosure of BPR developments by officers to their customers.
\end{abstract}

Keywords: 9P BPR Marketing Service Mix of BPR

Jasa perbankan menjadi objek yang sangat berkembang saat ini dan jasa ini memiliki persaingan yang ketat. Pada sektor perbankan dikenal jenis bank yang hanya melayani usaha mikro kecil dan menengah yakni bank perkreditan rakyat,

Bank Perkreditan Rakyat yang selanjutnya disebut BPR yaitu bank yang melaksanakan kegiatan usaha secara konvensional yang dalam kegiatannya tidak memberikan jasa dalam lalu lintas pembayaran sebagaimana dimaksud dalam Peraturan Otoritas Jasa Keuangan Nomor 20/Pojk.03/2014 Tentang Bank Perkreditan Rakyat.

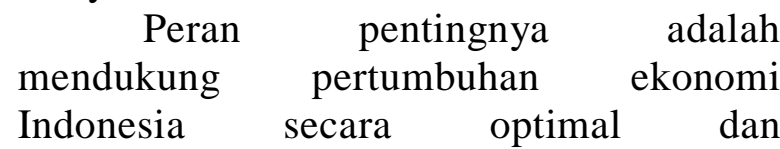
berkesinambungan, perlu meningkatkan ketahanan dan daya saing industri perbankan nasional. Bahwa untuk meningkatkan peran dan kontribusi industri BPR terhadap ekonomi daerah, dan memperkuat daya saing BPR, perlu upaya peningkatan ketahanan dan daya saing BPR melalui penguatan permodalan, penataan kepemilikan, dan peningkatan kualitas pengurus BPR. Undang-Undang Nomor 21 Tahun 2011 tentang Otoritas Jasa Keuangan (Lembaran Negara Republik Indonesia Tahun 2011 Nomor 111, Tambahan Lembaran Negara Republik Indonesia Nomor 5253).

Propinsi Riau merupakan daerah yang memiliki lokasi yang sangat strategis yakni sebagai pintu masuk dari negara luar seperti Singapura, Malaysia, Thailand, Filipina dan bahkan China. Letak yang sangat strategis menjadikan Riau sebagai ujung tombak dalam pelaksanaan MEA itu sendiri. Selain itu, Riau saat ini merupakan salah satu provinsi terkaya di Indonesia, dan sumber dayanya didominasi oleh sumber alam, terutama minyak bumi, gas alam, karet, kelapa sawit dan perkebunan serat. Tetapi, penebangan hutan yang merajalela telah mengurangi luas hutan secara signifikan, dari $78 \%$ pada 1982 menjadi hanya $33 \%$ pada 2005 . Rata-rata 160,000 hektar hutan habis ditebang setiap tahun, meninggalkan $22 \%$, atau 2,45 juta hektar pada tahun 2009. Deforestasi dengan tujuan pembukaan 
kebun-kebun kelapa sawit dan produksi kertas telah menyebabkan kabut asap yang sangat mengganggu di provinsi ini selama bertahun-tahun, dan menjalar ke negaranegara tetangga seperti Malaysia dan Singapura.

Pengukuran yang dilakukan dalam menilai bauran pemasaran jasa perbankan khususnya BPR masih belum banyak berkembang. Pada tulisan ini difokuskan pada pengembamgan dimensi bauran pemasaran jasa BPR berdasarkan kajian teori dan dipraktekkan pada BPR di Propinsi Riau.

Bauran pemasaran menurut beberapa ahli: "Marketing mix consist of the tools the organizations uses to create a desired response among a set of predefined consumers" (Solomon, Marshall and Stuart, 2012: 34; 51).Istilah marketing mix (bauran pemasaran) sendiri pertama kalinya dikemukakan oleh Neil Borden, dari Harvard Business School, dalam pidatonya di American Marketing Association (AMA) pada Tahun 1953 (Kartajaya, 2009; 202). Setelah itu, pada akhir 1950-an, McCarthy dari Michigan University mengklasifikasikan marketing-mix ini menjadi product, price, place dan promotion. Karena itulah, marketing mix ini sering disebut juga sebagai $4 \mathrm{P}$.

Beberapa pengertian bauran pemasaran menurut beberapa ahli: "Marketing mix consist of the tools the organizations uses to create a desired response among a set of predefined consumers" (Solomon, Marshall and Stuart, 2012; 51). (Maksudnya: Bauran pemasaran terdiri dari alat-alat organisasi menggunakan untuk membuat respon yang diinginkan antara satu set konsumen yang telah ditetapkan)

"Bauran Pemasaran (Marketing Mix) adalah kombinasi dari variabel-variabel pemasaran yang dapat dikendalikan oleh manajer untuk menjalankan strategi pemasaran dalam upaya mencapai tujuan perusahaan di dalam pasarsasaran tertentu" (Boyd, Walker and Larreche, alih bahasa Imam Nurmawan, 2012; 53).
Secara spesifik untuk bisnis jasa maka marketing mix dilengkapi dengan 3Ps (the expanded marketing mix) khusus jasa yaitu people, process dan physical evidence (Yazid, 2008: 19).

$$
\text { Alma, Buchari (2014: 336) }
$$
menjelaskan bauran pemasaran atau dikenal dengan istilah marketing mix manufaktur berupa $4 \mathrm{P}$ : product, price, place dan promotion. Untuk usaha perbankan sebagai produsen jasa, dilengkapi dengan $3 \mathrm{P}$ yaitu: people, physical evidence dan proccess.

Tjiptono, Fandy (2014: 42-44) bauran pemasaran jasa memiliki 8 dimensi antara lain: product, pricing, promotion, place, people, physical evidence, process, customer service. Lovelock dan Wright (2010:19) mengembangkan bauran pemasaran (marketing mix) menjadi integrated service management dengan menggunakan pendekatan 8Ps, yaitu: product, place and time, process, productivity and quality, people, promotion and education, physical evidence dan price.

Berdasarkan pendapat Lovelock dan Wright (2007:19); Alma (2014: 336); Tjiptono (2014: 42-44) maka dapat disintesakan bauran pemasaran jasa bank perkreditan rakyat menggunakan 8P ditambah dengan $1 \mathrm{P}$ untuk keunikan jasa yang diberikan yakni prioritas khusus priority jasa perbankan BPR pada usaha mikro, kecil dan menengah (UMKM), jadi model 9P bauran pemasaran jasa perbankan dapat dijelaskan sebagai berikut:

1) Product, produk merupakan bentuk penawaran organisasi jasa yang ditujukan untuk mencapai tujuan organisasi melalui pemuasan kebutuhan dan keinginan pelanggan. Dalam konteks ini produk bisa merupakan apa saja (baik yang berwujud fisik maupun yang tidak) yang dapat ditawarkan kepada pelanggan potensial untuk memenuhi kebutuhan dan keinginan tertentu. Keputusan bauran produk yang hadapi pemasaran jasa bisa sangat berbeda dengan yang dihadapi pemasar barang. Aspek pengembangan jasa baru juga

p.ISSN: $2407-800 X \quad$ e.ISSN: 2541-4356 
memiliki keunikan khusus yang berbeda dengan barang, yakni jasa baru sukar diproteksi dengan paten.

2) Price. Keputusan bauran harga berkenaan dengan kebijakan strategic dan taktikal, seperti tingkat harga, struktur diskon, syarat pembayaran dan tingkat diskriminasi harga diantara berbagai kelompok pelanggan. Pada umumnya aspek-aspek ini mirip dengan yang biasa dijumpai pemasar barang. Akan tetapi, apa pula perbedaannya, yaitu bahwa karakteristik intangible jasa menyebabkan harga menjadi indikator signifikan atas kualitas. Karakteristik personal dan non tranferabel pada beberap tipe jasa memungkinkan diskriminiasi harga pada pasar tersebut, sementara banyak pula jasa yang dipasarkan oleh sector public dengan harga yang disubsidi atau bahkan gratis, hal ini menyebabkan kompleksitas dalam penetapan harga jasa.

3) Place. Keputusan distribusi menyangkut kemudahan akses terhadap jasa bagi para pelanggan potensial. Keputusan ini meliputi keputusan lokasi fisik, keputusan mengenai penggunaan perantara untuk meningkatkan aksesibelitas jasa bagi para pelanggan, dan keputusan non lokasi yang ditetapkan demi ketersediaan jasa.

4) Promotion. Bauran promosi tradisional meliputi berbagai metode untuk mengkomunikasikan manfaat jasa kepada pelanggan potensial dan actual. Metode tersebut terdiri atas periklanan, promosi penjualan, direct marketing, personal selling, dan public relation. Meskipun secara garis besar bauran promosi untuk barang sama dengan jasa, promosi jasa sering kali membutuhkan penekanan tertentu pada upaya meningkatkan kenampakan tangiblitas jasa. Selain itu, dalam kasus pemasaran jasa personal produksi juga menjadi bagian penting dalam bauran promosi.

5) People. Bagi sebagian besar jasa, orang merupakan unsur vital dalam bauran pemasaran. Bila produksi dapat $\begin{array}{lcr}\text { dipisahkan dengan } & \text { konsumsi, } \\ \text { sebagaimana } & \text { dijumpai } & \text { dalam }\end{array}$ kebanyakan kasus pemasaran barang manufaktur, pihak manajemen biasanya dapat mengurangi pengaruh langsung sumber daya manusia terhadap output akhir yang diterima pelanggan. Oleh sebab itu, setiap organisasi jasa terutama yang tingkat kontaknya dengan pelanggan tinggi harus secara jelas menentukan apa yang diharapkan dari setiap karyawan dalam interaksinya dengan pelanggan. Untuk mencapai standar yang ditetapkan, metode-metode rekrutmen, pelatihan, pemotivasian, dan penilaian kinerja karyawan tidak dapat dipandang semata-mata sebagai keputusan personalia, semua itu juga merupakan keputusan bauran pemasaran yang penting.

6) Physical evidence. Karakteristik intangible pada jasa menyebabkan pelanggan potensial tidak bisa menilai suatu jasa sebelum mengkonsumsinya. Ini menyebabkan resiko yang dipersepsikan konsumen dalam keputusan pembelian semakin besar. Oleh sebab itu, salah satu unsur penting dalam bauran pemasaran adalah upaya mengurangi tingkat resiko tersebut dengan jalan menawarkan bukti fisik dari karakteristik jasa.

7) Proccess. Proses produksi atau operasi merupakan faktor penting bagi konsumen high contact service yang kerap kali juga berperan sebagai ko produser jasa bersangkutan. Berbagai isu muncul sehubungan dengan batas produsen dan konsumen dalam hal alokasi fungsi-fungsi produksi. Dalam bisnis jasa, manajemen pemasaran dan manajemen operasi terkait erat dan sulit dibedakan dengan tegas.

8) Productivity. Produktivitas dan kualitas, yang sering juga dipisahkan satu sama lain, harus dilihat sebagai dua sisi mata uang yang sama. Tidak ada perusahaan jasa yang sanggup menangani kedua elemen ini secara 
sendiri-sendiri. Meningkatkan produktivitas sangat penting untuk menjaga agar biaya tetap terkendali, tetapi manajer harus berhati-hati untuk tidak mengurangi tingkat layanan yang tidak disukai pelanggan bahkan juga karyawan.

9) Priority, priority ditegaskan pada masalah kekhususan pelayanan yang diberikan jasa perbankan seperti yang diberikan BPR kepada pengusaha usaha mikro, kecil dan menengah (UMKM).

\section{METODE}

Jenis penelitian yang digunakan dalam penelitian ini adalah deskriptif. Penelitian deskriptif adalah penelitian yang bertujuan untuk memperoleh deskripsi tentang bauran pemasaran jasa perbankan Bank BPR se Propinsi Riau. Metode penelitian yang digunakan adalah descriptive survey dan metode explanatory survey.

Adapun teknik pengumpulan data dalam penelitian ini sebagai berikut: Kuesioner, Kuesioner dilakukan melalui penyebaran daftar pertanyaan langsung untuk memperoleh data-data yang dari responden. Bentuk pertanyaan menggunakan 5 (lima) tingkatan dengan skala Likert dari skor $1 \mathrm{~s} / \mathrm{d}$ 5. Nilai 1 (Sangat tidak setuju); nilai 2 (tidak setuju); nilai 3 (cukup); nilai 4 (setuju); dan nilai 5 (sangat setuju) yang diberikan kepada para pelanggan yang menjadi responden terpilih. Observasi, Observasi adalah mengadakan pengamatan langsung untuk mendapatkan informasi yang lebih akurat mengenai variabel yang diteliti dengan menggunakan sumber data sesuai dengan unit observasi atau analisa. Dokumentasi. Teknik dokumentasi dilakukan dengan menelaah dan mengkaji catatan atau laporan dan dokumen-dokumen lain dari berbagai lembaga yang ada kaitannya dengan permasalahan yang diteliti.

Populasi dalam penelitian ini adalah seluruh pelanggan kredit pada Bank Perkreditan Rakyat (BPR) di Propinsi Riau. Jumlah BPR yang terdapat di Propinsi Riau sebanyak 33 BPR, berdasarkan POJK No 20/POJK.03/2014 pasal 5 ayat 1, zona BPR berdasarkan modal disetor terdiri dari; zona 1 dengan modal di setor sebesar Rp. 14 Milyar, bagi BPR yang didirikan pada zona 2 dengan modal di setor sebesar 8 Milyar, bagi BPR yang didirikan pada zona 3 dengan modal di setor sebesar 6 Milyar, sedangkan BPR yang didirikan pada zona 4 dengan modal di setor sebesar 4 Milyar. Pembagian zona sebagaimana di atas. Ditentukan oleh OJK berdasarkan potensi ekonomi wilayah dan tingkat persaingan lembaga keuangan di wilayah Kabupaten atau Kota yang bersangkutan, maka di Propinsi Riau telah ditetapkan oleh OJK dibagi kepada dua zona yakni zona 2 dan zona 4. Zona 2 (Kota Pekanbaru terdapat 17 BPR), sedangkan zona 4 terdapat 16 BPR (11 Kabupaten atau Kota meliputi: Kampar, Bengkalis, Pelalawan, Kuantan Singingi, Dumai, Rokan Hulu, Rokan Hilir, Indragiri Hulu, Indragiri Hilir, Kepulauan Meranti dan Siak), namun dari 33 BPR yang diambil dalam penelitian ini sebanyak 19 BPR yang tersebar pada zona 2 sebanyak 8 BPR dan zona 4 sebanyak 11 BPR. Hal ini atas pertimbangan bahwa terdapat BPR yang kurang sehat, dengan jumlah pelanggan sebanyak 21.725 pelanggan.

Adapun teknik yang digunakan dalam pengambilan sampel adalah dengan menggunakan Cluster Proporsional Random Sampling, yaitu: teknik sampling yang memberikan peluang yang sama bagi setiap unsur populasi untuk dipilih menjadi sampel.Penentuan jumlah sampel dari populasi tertentu yang dikembangkan oleh Slovin, ukuran sampel yang diambil minimal 393 dari seluruh populasi pelanggan kredit BPR di Propinsi Riau.

Analisa dan interpretasi data dalam penelitian ini menggunakan metode deskriptif. data yang masuk dengan cara dikelompokkan dan ditabulasi kemudian diberi penjelasan.

\section{HASIL}

Berdasarkan hasil tanggapan responden mengenai variabel bauran pemasaran jasa BPR di Propinsi Riau dengan nilai total skor sebesar 3,2750 
masuk dalam kategori cukup baik, dari 18 indikator penelitian dapat diketahui bahwa terdapat sebanyak 6 indiaktor yang nilainya di bawah nilai total rata-rata, ini bermakna yang menjadi penyebab masih cukup baiknya bauran pemasaran jasa BPR se Propinsi Riau antara lain Karena: Kurangnya ketersediaan variasi kredit yang menjadi produk pelayanan pada Bank BPR; Kurangnya kesesuaian variasi kredit yang ditawarkan dengan kebutuhan nasabah BPR; Rendahnya kesanggupan nasabah mencicil angsuaran BPR yang ditetapkan; Kurangnya ketersediaan tempat layanan BPR kepada nasabah; Kurangnya keterjangkauan nasabah BPR mendatangi tempat layanan; dan Kurangnya keterbukaan perkembangan BPR oleh petugas kepada nasabahnya.

Rekapitulasi hasil jawaban responden mengenai Bauran Pemasaran Jasa memiliki rata-rata 3,2750 dan standar deviasi 0,9886 dinyatakan termasuk kategori cukup baik, hal ini mengindikasikan bahwa BPR se Propinsi Riau, sangat bervariatif, dimana katagorinya dari bauran pemsaran jasa tidak efektif menuju sangat efektif. Oleh karena itu masih perlu adanya upaya peningkatan Bauran Pemasaran Jasa dan lebih merata.

Berdasarkan hasil penyebaran data pada 240 orang responden dari 17 BPR se Propinsi Riau selama kurun waktu Agustus 2016 hingga Januari 2017 dapat diketahui kondisi bauran pemasaran jasa BPR di Propinsi Riau yang dalam kategori cukup baik. Hal ini disebabkan karena masih kurangnya ketersediaan variasi kredit yang menjadi produk pelayanan pada Bank BPR, hal ini apabila dikaitkan dengan lama meminjam responden ke BPR, dimana dengan lama meminjam di bawah 10 tahun responden khusus dari UMKM membutuhkan variasi kredit yang lebih banyak. Kemudian juga karena kurangnya kesesuaian variasi kredit yang ditawarkan dengan kebutuhan nasabah BPR, variasi kredit yang dibutuhkan pelanggan seperti kredit bakulan, kredit agribisnis, kredit talangan (pendidikan, pesta). Juga karena rendahnya kesanggupan nasabah mencicil angsuran BPR yang ditetapkan, kurangnya ketersediaan tempat layanan BPR kepada nasabah. Kurangnya keterjangkauan nasabah BPR mendatangi tempat layanan dan kurangnya keterbukaan informasi perkembangan BPR oleh petugas kepada nasabahnya. Hal ini menyebabkan pelanggan membutuhkan banyak pilihan dari BPR.

Upaya yang dapat dilakukan untuk meningkatkan bauran pemasaran jasa pada BPR se Propinsi Riau menurut Ir. H. Safri, M.Si selaku Sekrterits Jendral Persaturan BPR Pemerintah Daerah (PERBAMIDA) dengan cara menerapkan sistem informasi BPR yang lebih komprehensif dalam mensinerjikan antara kebutuhan pelanggan dengan kemampuan BPR memberikan layanan. Masalah kurang ketersediaan variasi kredit yang menjadi produk pelayanan pada Bank BPR dapat diatasi dengan terjalinnya sistem BPR yang online. Kemudian untuk mengatasi masalah kurangnya kesesuaian variasi kredit yang ditawarkan dengan kebutuhan nasabah BPR itu dapat diatasi dengan berbagai masukan dari nasabah untuk dapat dipertimbangkan dan diakomodir dalam rangka memberikan layanan variasi produk baru. melalui sistem informasi yang online dan update, berbagai masukan dari nasabah dapat dihimpun. Masalah rendahnya kesanggupan nasabah mencicil angsuran BPR yang ditetapkan dapat disiasati dengan melakukan penjadwalan ulang pinjaman dari nasabah dan dari pihak BPR perlu meningkatkan peran serta dalam bentuk pendekatan kepada nasabah untuk menumbuhkan semangat dalam berusaha sehingga akan diharapkan nantinya akan mampu mencicil angsuran kembali. Melalui penerapan sistem informasi online maka akan dapat mengeatasi masalah layanan produk BPR kepada nasabah dan juga dapat mengatasi masalah tempat layanan dan keterbukaan informasi yang dapat meyakinkan nasabah BPR untuk bertransaksi.

\section{PEMBAHASAN}

Bauran pemasaran jasa dengan menggunakan model 9P, apabila dilihat dari 
seuruh dimensi bauran pemasaran jasa diketahui dimensi tertinggi adalah pada dimensi: promotion, people, physical evidence, productivity, priority. Sedangkan dimensi di bawah nilai total rata-rata adalah produk, price, place, process.

Nilai di bawah rata-rata dapat dilihat dari dimensi Product dengan 2 indikator pertanyaan dengan skor yang diperoleh sebesar 2,7888, hal ini mengindikasikan bahwa perusahaan selalu dituntut memberikan pelayanan jasa yang baik dan selalu berupaya menekankan adanya perbaikan berkelanjutan atas pelayanan jasa yang diberikan kepada nasabah. Nilai yang paling rendah dari dimensi ini adalah pada pertanyaan "Kesesuaian variasi kredit yang ditawarkan dengan kebutuhan nasabah BPR", hal ini memperlihatkan bahwa BPR se Propinsi Riau belum mampu memberikan kesesuaian variasi kredit yang diberikan dengan kebutuhan nasabah.

Apabila dilihat dari indikator ketersediaan variasi kredit yang menjadi produk pelayanan pada Bank BPR dengan skor yang diperoleh sebesar 2,9262 masuk dalam kategori cukup baik dan ini bermakna bahwa BPR selama ini memiliki cukup variasi kredit yang diberikan kepad nasabah. Beberapa variasi kredit yang diberikan kepada nasabahnya antara lain adalah perkreditan, tabungan, deposito, pembayaran online dan transfer antar bank. Untuk produk perkreditan diberi nama kredit wirausaha, untuk membantu dan memberikan pelayanan serta kemudahan bagi para pengusaha Mikro Kecil dan Menengah (UMKM) dalam memperoleh Dana Tunai untuk mengembangkan usaha perdagangan dan jasa. Adapun sektor perkreditan ini antara lain: sektor perdagangan (Grosir, eceran , kedai harian, kelontong dan lainlain); sektor perindustrian (Konveksi, industri rumah tangga,perabot, pembuatan pakan ikan dan lain-lain); sektor rumah makan dan restoran; sektor jasa dunia usaha (Penginapan, klinik kesehatan, perbengkelan, transportasi dan lain-lain); sektor jasa umum (Loundry, rental komputer, internet, wartel dan lain-lain).
Dari bebrapa variasi produk yang disediakan BPR tersebut menunjukkan sudah cukup baik dan selanjutnya pada indikator kesesuaian variasi kredit yang ditawarkan dengan kebutuhan nasabah BPR, dengan skor yang dihasilkan sebesar 2,6514 masuk kategori cukup baik dan ini menunjukkan bahwa produk yang ditawarkan merupakan bentuk permintaan pasar, analisa dilakukan terhadap kebutuhan pasar akan produk perbankan dan ini dilakukan dan disediakan produk yang demikian. Seperti contohnya adalah produk kredit bakulan, dimana kebutuhan akan uang modal bagi usaha bakulan sifatnya hanya harian dan kebutuhan modal harian ini disediakan dalam rangka membeli barang dagangan dan pada hari tersebut juga barang dagangan dijual. Hasil penjualan pada hari yang bersamaan akan dihitung dan keuntungannya sebagiannya akan dibayarkan untuk mencicil hutang ke BPR dan ini juga bagi pihak BPR datang langsung ke pasar dan pedagang tidak perlu untuk menyetorkan langsung ke BPR.

Kemudian dilihat dari dimensi Price dengan 2 indikator pertanyaan dengan skor 2,6438, hal ini mengindikasikan bahwa perusahaan selalu dituntut memberikan harga atas pelayanan jasa yang memuaskan dan selalu berupaya menekankan adanya perbaikan kualitas jasa yang diberikan kepada nasabah. Nilai yang paling rendah dari dimensi ini adalah pada pertanyaan "Ketersediaan tempat layanan BPR kepada nasabah", hal ini memperlihatkan bahwa BPR se Propinsi Riau belum mampu memberikan ketersediaan tempat layanan BPR kepada nasabah yang memadai.

Berdasarkan hasil penelitian jawaban mengenai ketersediaan tempat layanan BPR kepada nasabah dengan skor sebesar 2,6387 masuk dalam kategori cukup. Ini menunjukkan BPR selama ini sudah menyediakan tempat pembayaran cicilan dengan cukup baik. BPR sebagain besar menerapkan layanan jemput bola, maksudnya adalah jalinan yang dilakukan dengan pola tertentu akan memberikan pengaruh khususnya terhadap kelancaran

p.ISSN: $2407-800 X \quad$ e.ISSN: 2541-4356 
pengembalian kredit pada Bank PD BPR Sarimadu. Komunikasi berkelanjutan dilakukan dengan rutinnya pihak Bank PD BPR Sarimadu mendatangi nasabah melalui pembinaan dan pengawasan. Pembinaan dan pengawasan yang dilakukan oleh Bank PD BPR Sarimadu dapat mencegah masalahmasalah dalam tingkat pengembalian kredit. Rutinnya komunikasi yang dilakukan ini dapat mengetahui permasalahan yang dihadapi nasabah sehingga dapat cepat dicarikan solusinya. Adanya pola komunikasi interaksional, maka nasabah diberikan kesempatan lebih untuk terus mencari informasi dan berkomunikasi dengan pihak Bank PD BPR Sarimadu.

Terakhir dilihat dari dimensi Process dengan 2 indikator pertanyaan dinyatakan cukup baik, hal ini mengindikasikan bahwa perusahaan selalu dituntut untuk memberikan proses pelayanan yang handal dan selalu berupaya meningkatkan proses pelayanan yang lebih baik lagi bagi nasabah. Nilai yang paling rendah dari dimensi ini adalah pada pertanyaan "Keterbukaan perkembangan BPR oleh petugas kepada nasabahnya", hal ini memperlihatkan bahwa BPR se Propinsi Riau belum memadai dalam berbagi informasi mengenai perkembangan BPR oleh petugas kepada nasabahnya.

Indikator yang ditanyakan tentang proses ini berkaitan dengan masalah ketaatan menjalankan prosedur dalam memperoleh kredit dan juga berkaitan dengan keterbukaan perkem-bangan BPR oleh petugas kepada nasabahnya. Berdasarkan hasil penelitian berkaitan dengan masalah ketaatan menjalankan prosedur dalam memperoleh kredit dengan skor yang diperoleh sebesar 3,4631 masuk dalam kategori baik dan ini menjadi sebuah kondisi yang mana dirasakan nasabah ketaatan kepada prosedur yang ada memang lebih longgar maksudnya nasabah merasa prosedur tersebut masih saja bisa dikondisikan. Dari sisi BPR, sesungguhnya prosedur yang dibuat sebagai bentuk jaminan langkah yang ada dalam mendapatkan permodalan dan ini juga merupakan tanggapan dari persyaratan yang ditetapkan oleh OJK dalam rangka memberikan pinjaman kepada masyarakat. Namun oleh karena segala persyaratan yang ditetapkan dan dinilai oleh karyawan yang berasal dari daerah tersebut menjadikan persyaratan kredit sudah dimiliki informasinya.

$$
\text { Pada indikator keterbukaan }
$$
perkembangan BPR oleh petugas kepada nasabahnya dengan skor yang dihasilkan sebesar 2,9211 masuk dalam kategori cukup baik dan ini menunjukkan bahwa sebagian daripada nasabah kurang menginginkan informasi perkembangan BPR namun bagi nasabah yang menginginkan kondisi tersebut, maka sesungguhnya BPR sudah membuat informasi dalam website dan juga profil dari BPR yang bisa langsung di baca nasabah melalui internet atau android mereka masing-masing.

Jadi dari uraian mengenai proses dalam rangka bentuk bauran pemasaran maka dapat diketahui adanya proses pemberian kredit yang lebih fleksibel kepada nasabah dan juga informasi perkembangan BPR sebagai bentuk rasa aman bagi nasabah juga disampaikan dalam website dan ini menjadikan proses BPR dalam memberikan pelayanan kepada nasabah dinilai baik.

Sedangkan nilai yang di atas ratarata dapat dilihat dari dimensi Promotion dengan 2 indikator pertanyaan dinyatakan baik dengan skor yang diperoleh sebesar 3.5064, hal ini mengindikasikan bahwa perusahaan selalu dituntut untuk memberikan promosi yang efektif dan selalu berupaya menekankan adanya perbaikan penggunaan media promosi yang tepat sehingga memudahkan informasi yang diterima nasabah. Nilai yang paling rendah dari dimensi ini adalah pada pertanyaan "Efektifitas penjemputan setoran oleh petugas BPR dalam proses transaksi", hal ini memperlihatkan bahwa BPR se Propinsi Riau belum efektif dalam mengelola setoran nasabah yang memadai.

Indikator promosi yang dilakukan seperti ditanyakan kepada responden berkenaan dengan efektifitas penjemputan setoran oleh petugas BPR dalam proses transaksi dengan skor sebesar 3.3893

$$
\text { p.ISSN: } 2407-800 X \quad \text { e.ISSN: 2541-4356 }
$$


menunjukkan bahwa promosi yang dilakukan BPR sudah cukup baik. Berdasarkan hasil wawancara dengan ketua Perbarindo bahwa agar bisnis BPR terus tumbuh dan berkembang), manajemen BPR mesti punya Strategi Bisnis yang jitu, seperti : Tetap fokus pembiayaan BPR hanya kepada usaha produktif skala mikro dan kecil yang sudah dikenal tabiat \& karakteristiknya, begitu pula usahakan agar tingkat suku bunga kredit pun kompetitif dan terjangkau. Sedapat mungkin melayani kemauan UMK. Mereka umumnya tidak mau dibikin ribet dalam urusan persyaratan dan prosedur bank, sedapat mungkin buatlah syarat yang sederhana, cepat dan ringkas. Selain itu amatlah penting membangun komunikasi dan silahturahmi dengan nasabah untuk memantau perkembangan usaha mereka. Meski berpredikat sebagai "banknya wong cilik", BPR tetap butuh dukungan Teknologi Informasi (TI) dalam operasionalnya agar mampu meningkatkan kualitas layanan yang jauh lebih cepat dan efisien. Kalau mau menambah kantor cabang atau kas, pertimbangkanlah rencana itu dilakukan karena jumlah nasabah yang terus melonjak dan membutuhkan keamanan, menjaga kedekatan dan kemudahan dalam bertransaksi.

Kemudian pada indikator kesiapan karyawan menghadapi calon nasabah BPR dimana jelas dapat diketahui bahwa skor dari tanggapan responden sebesar 3,6234 masuk dalam kategori baik dan ini menunjukkan bahwa karyawan sudah siap memberikan pelayanan kepada nasabahnya. Meski BPR berorientasi bisnis, namun harus tetap membaur dan menjadi bagian dari masyarakat setempat. Hal ini penting dalam membangun relasi dan ikatan batin melalui keterlibatan BPR dalam kegiatan sosial kemasyarakatan di lingkungan sekitar, misalnya, hari raya keagamaan, perayaan hari besar dan hajatan nasabah.

Dimensi People dengan 2 indikator pertanyaan dinyatakan baik dengan skor yang diperoleh mencapai 3.5687, hal ini mengindikasikan bahwa perusahaan selalu dituntut untuk menyediakan petugas yang handal dan selalu berupaya menekankan adanya peningkatan kompetensi pergawai sehingga dapat memberikan pelayanan yang lebih baik kepada nasabah. Nilai yang paling rendah dari dimensi ini adalah pada pertanyaan "Kesediaan BPR melakukan monitoring penggunaan pinjaman nasabah", hal ini memperlihatkan bahwa BPR se Propinsi Riau belum mampu melakukan monitoring penggunaan pinjaman nasabah.

Pada dimensi people ini menggunakan dua indikator yang berkenaan dengan kesiapan karyawan menghadapi wilayah kerja BPR dan juga berkaitan dengan pengawasan pihak BPR memonitor penggunaan dana pinjamannya. Pada indikator kesiapan karyawan menghadapi wilayah kerja BPR dengan skor sebesar 3.5802 masuk dalam kategori baik dan ini menunjukkan bahwa karyan sudah memiliki kesiapan karyawan menghadapi wilayah kerja BPR. Pihak BPR melakukan rekrutmen karyawan berasal dari warga setempat, dimana pemuda dengan memiliki persyaratan yang memadai untuk menjadi karyawan BPR lebih diutamakan mereka yang penduduk setempat, sehingga mereka sudah mengenal daerah kerja BPR dan dengan mudah dan bahkan karyawan tersebut sekaligus menjadi tempat promosi dan bahkan keluarga dari karyawan akan memberikan dukungan dalam menyampaikan berbagai program BPR. Hal ini dinilai efektif dalam rangka menjadikan karyawan siap menghadapi kondisi kerja BPR yang memang langsung berbaur dengan masyarakat.

Kemudian pada indikator kesediaan BPR melakukan monitoring penggunaan pinjaman nasabah ini dilakukan sesuai dengan tanggapan responden sebesar 3.5573 masuk dalam kategori baik dan ini menunjukkan adalah karyawan sebagai orang yang memberikan pelayanan langsung kepada nasabah memberikan pengawasan dan terkadang memang dijadikan tempat bertanya bagi masyarakat dan nasabah dalam penggunaan dana pinjaman. Walaupun ada sebagian dari masyarakat dalam menggunakan dana

$$
\text { p.ISSN: } 2407-800 X \quad \text { e.ISSN: 2541-4356 }
$$


pinjaman belum sesuai dengan rencananya, hal ini adalah sebagain kecil saja.

Dimensi Physical evidence dengan 2 indikator pertanyaan dinyatakan baik dengan skornya sebesar 3.6349, hal ini mengindikasikan bahwa perusahaan selalu dituntut untuk memberikan fasilitas fisik yang handal dan selalu berupaya meningkatkan fasilitas yang diberikan kepada nasabah. Nilai yang paling rendah dari dimensi ini adalah pada pertanyaan "Kesediaan BPR mengevaluasi pinjaman nasabah di masa depan", hal ini memperlihatkan bahwa BPR se Propinsi Riau belum memadai mengevaluasi pinjaman nasabah di masa depan.

Pada indikator kesediaan BPR mengevaluasi pinjaman nasabah di masa depan dengan skor yang diperoleh sebesar 3.3817 menunjukkan bahwa BPR cukup memiliki Kesediaan BPR mengevaluasi pinjaman nasabah di masa depan. Evaluasi yang dilakukan pihak calon nasabah berkaitan dengan masa depan permodalan yang mereka peroleh memang juga sebagai usaha untuk menjaga nasabah agar lebih loyal kepada BPR dan menaruh kepercayaan kepada BPR dan ini menjadikan BPR selalu mendapatkan tempat di masyarakat. Nasabah mendapatkan jaminan informasi yang layak mereka dapatkan menjadikan ukuran keberhasilan kedepannya. Sehingga bagi masyarakat yang menjalankan usaha mereka akan dapat merencanakan bisnisnya ke depan pula.

Kemudian pada indikator kejelasan prosedur memperoleh kredit dengan skor jawaban responden sebesar 3.8880 yang masuk dalam kategori baik menunjukkan bahwa adanya kejelasan prosedur yang semestinya dilalui oleh nasabah dalam memperoleh kredit, prosedur ini dijelaskan kepada calon nasabah dan mereka mendapatkan informasi mengenai prosedur ini. Informasi mengenai prosedur tersebut pada dasarnya sudah dimiliki dan nasabah selalu bertanya jika ingin meminjam dana bagaimana prosedurnya. Hal inilah yang terkadang dalam penerapan prosedur lebih fleksibel bagi calon nasabah. Sebagian nasabah khususnya nasabah yang sudah berulang menjadi nasabah sudah dengan mudah mendapatkan pinjaman melalui BPR dengan hanya mengupdate identitas maka mereka mendapatkan pinjaman. Hal ini dikarenakan adanya unsur kepercayaan dari pihak BPR kepada nasabah tersebut.

Dimensi Productivity dengan 2 indikator pertanyaan dinyatakan cukup baik, hal ini mengindikasikan bahwa perusahaan selalu dituntut untuk memberikan produktivitas yang tinggi dan selalu berupaya meningkatkan produktivitasnya sehingga dapat memberikan pelayanan yang lebih baik kepada nasabah. Nilai yang paling rendah dari dimensi ini adalah pada pertanyaan "Kegairahan pelayanan BPR kepada nasabahnya", hal ini memperlihatkan bahwa BPR se Propinsi Riau belum memadai menunjukkan semangat yang tinggi dalam pelayanan kepada nasabahnya. Pada dimensi produktivitas ini ditanyakan kepada nasabah sebanyak dua indikator antara lain: Kegairahan pelayanan BPR kepada nasabahnya dan pemberian prioritas kredit kepada nasabah prima. Melihat kondisi pelayanan yang diberikan kepada nasabah maka dimensi produktifitas menjadi sorotan dijelaskan bahwa adanya kegairahan pelayanan BPR dengan skor mencapai 3,4249 ini menunjukkan adanya usaha dari pihak BPR sudah mulai menerapkan sistem informasi dalam pelaksanaan proses kerja mereka, sehingga nasabah bisa melihat kondisinya dan juga kegairahan dalam memberikan pelayanan transaksi dimana pelayanan yang dilakukan sampai kepada kebutuhan transaksi keuangan sedetil pembayaran online juga diberikan.

Dari uraian produktivitas tersebut, maka BPR sudah memiliki produktivitas yang berkembang dan sesuai dengan selera pasar dan ini dilakukan agar eksistensi BPR tetap terjaga dan juga menjadikan BPR benar-benar sebagai mitra keuangan pengusaha kecil dalam rangka mengembangkan usahanya.

Dimensi Prority dengan 2 indikator

p.ISSN: $2407-800 X \quad$ e.ISSN: 2541-4356 
pertanyaan dinyatakan baik dengan skor 3,4491, hal ini mengindikasikan bahwa perusahaan selalu dituntut untuk memberikan prioritas yang tinggi dan selalu berupaya meningkatkan priorotasnya sehingga dapat memberikan pelayanan yang lebih baik kepada nasabah. Nilai yang paling rendah dari dimensi ini adalah pada pertanyaan "Pemberian prioritas layanan kepada nasabah prima", hal ini memperlihatkan bahwa BPR se Propinsi Riau belum memadai dalam memberikan prioritas layanan kepada nasabah prima.

Pada indikator pemberian prioritas layanan kepada nasabah prima memiliki skor sebesar 3,4377 masuk dalam kategori baik dimana bagi BPR saat ini sudah adanya usaha pemberian prioritas layanan kepada nasabah prima. Nasabah-nasabah yang sudah berulang kali mamakai jasa BPR dan dikategorikan lancar, mereka mendapatkan fasilitas pelayanan ekstra dari BPR, hal ini dilakukan BPR untuk menjaga tetap demikian dan ini menjadikan BPR lebih mendapatkan kepercayaan dari nasabahnya dalam masalah permodalan.

Kemudian pada indikator kesanggupan nasabah mencicil angsuran BPR yang ditetapkan dengan skor sebesar 3,4606 menunjukkan bahwa adanya kemampuan dari pihak nasabah dalam mencicil, karena hal ini sudah diperhitungkan sebelumnya. Dari pihak nasabah sudah mengukur kemampuannya dalam mencicil dan juga dari pihak BPR sudah memperkirakan kondisi kemampuan nasabah dalam mencicil angsuran yang ada.

\section{SIMPULAN}

Bauran pemasaran jasa BPR di Propinsi Riau yang dalam kategori cukup baik. Hal ini disebabkan karena masih kurangnya ketersediaan variasi kredit yang menjadi produk pelayanan pada Bank BPR. Kemudian juga karena kurangnya kesesuaian variasi kredit yang ditawarkan dengan kebutuhan nasabah BPR. Juga karena rendahnya kesanggupan nasabah mencicil angsuran BPR yang ditetapkan, kurangnya ketersediaan tempat layanan BPR kepada nasabah. Kurangnya keterjangkauan nasabah BPR mendatangi tempat layanan dan kurangnya keterbukaan informasi perkembangan BPR oleh petugas kepada nasabahnya. Menurut expert judgment dalam bauran pemasaran yang rendah ini dikarenakan belum diterapkannya sistem informasi online sehingga terdapat banyak produk layanan yang tertutup peluangnya.

\section{DAFTAR RUJUKAN}

Alma, Buchari. 2014. Manajemen Pemasaran dan Pemasaran Jasa. Bandung: Alfabeta.

Boyd, Walker and Larreche, alih bahasa Imam Nurmawan, 2008, Manajemen Pemasaran Suatu PendekatanStrategis Dengan Orientasi Global Jilid I. Alih bahasa: Imam Nurmawan. Jakarta: Erlangga.

Fandy Tjiptono, 2000, Manajemen Jasa, Penerbit Andi Yogyakarta

Kartajaya, 2009, New Wave Marketing, The World is Still. Round The Market is Already Flat.Gramedia. Indonesia.

Kurt, David L and Kenneth Clow.1998. Service Marketing. Singapore. John Wiley \& Sons, Inc.: 24-30.

Kotler and Keller, 2012, Marketing Management Edisi 14, Global Edition.Pearson Prentice. Hall.

Kotler and Keller, 2016, Marketing Management Edisi 12, Jilid 1, Global Edition.Pearson Prentice. Hall.

Kotler and Amstrong, 2010. Manajemen Pemasaran. Edisi 13 Jilid 2. Jakarta. Erlangga 
Lovelock. C, 2010, Pemasaran Jasa. Peraturan Otoritas Jasa Keuangan Nomor Erlangga, Jakarta 20/POJK.03/2014 tentang Bank Perkreditan Rakyat

Lupiyoadi, Hamdani. 2006. Manajemen Pemasaran Jasa, Edisi Kedua. Penerbit Salemba Empat. Jakarta.

BPS, 2016, Riau dalam Angka, Pekanbaru.

Yazid. 2008. Pemasaran Jasa. Edisi Kedua. Ekonisia. Yogyakarta.

Undang-Undang Dasar 1945 pasal 33 tentang perekonomian

Undang-Undang Nomor 21 Tahun 2011 tentang Otoritas Jasa Keuangan (Lembaran Negara Republik Indonesia Tahun 2011 Nomor 111, Tambahan Lembaran Negara Republik Indonesia Nomor 5253) http://www.bi.go.id/id/statistik/perbankan/b pr-konvensional 